\title{
Corrigendum: Guideline on the management of occupational and non-occupational exposure to the human immunodeficiency virus and recommendations for post-exposure prophylaxis: 2015 Update
}

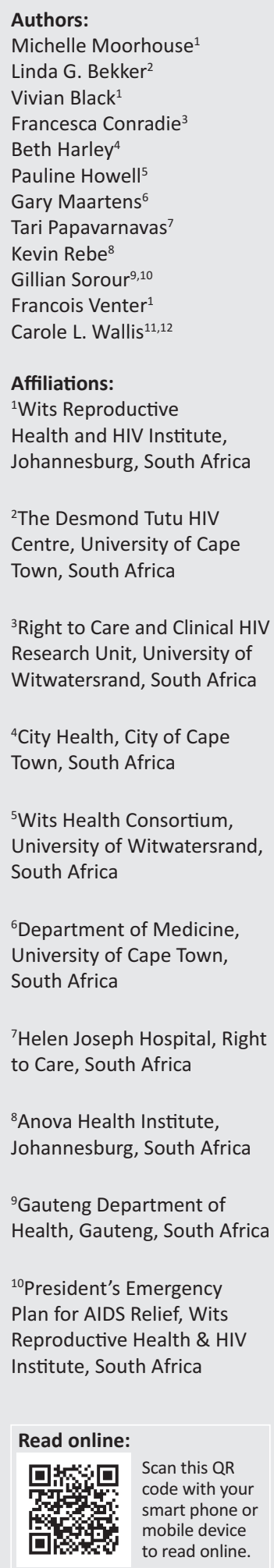

The authors apologise for two oversights in Table 1: One was due to an incorrect recommendation; the other was an omission.

Table 1 states that, 'RAL is recommended as preferred third drug where available for HIV PEP in children. If RAL unavailable, then ATV/ $\mathrm{r}$ is recommended.' This has been deleted and the correct recommendation made.

Please see below the revised Table 1.

Additionally, information about dosing was omitted. This information has now been added in Appendix 1 below.

TABLE 1: Summary of guidelines on post-exposure prophylaxis for HIV in adults, adolescents and children.

\begin{tabular}{|c|c|}
\hline Guideline & Recommendation \\
\hline Number of antiretroviral drugs & HIV PEP regimens should contain three drugs \\
\hline \multirow[t]{3}{*}{$\begin{array}{l}\text { Preferred PEP regimen for adults } \\
\text { and adolescents }\end{array}$} & $\begin{array}{l}\text { TDF }+3 T C / F T C \text { (preferably as fixed-dose combination) is recommended as preferred PEP } \\
\text { backbone }\end{array}$ \\
\hline & $\begin{array}{l}\text { RAL is recommended as preferred third drug for PEP (except in pregnant women, where ATV/r } \\
\text { is the recommended third drug) }\end{array}$ \\
\hline & Alternative third drugs include ATV/r, LPV/r, DRV/r or EFV \\
\hline \multirow[t]{2}{*}{$\begin{array}{l}\text { Preferred PEP regimen for children } \\
\leq 35 \mathrm{~kg} \text { or unable to swallow tablets }\end{array}$} & $\begin{array}{l}\text { AZT + 3TC is recommended as preferred backbone for HIV PEP in children } \leq 35 \mathrm{~kg} \text { (substitute } \\
\text { with d4T if AZT poorly tolerated) }\end{array}$ \\
\hline & $\begin{array}{l}\mathrm{LPV} / \mathrm{r} \text { is recommended as the third drug for HIV PEP in children. Where RAL is available, then } \\
\text { it can be used in children over } 2 \text { years of age in preference to LPV/r due to better tolerability. } \\
\text { In children over } 6 \text { years of age who can swallow tablets, ATV/r is another better tolerated } \\
\text { alternative to LPV/r where available. }{ }^{+}\end{array}$ \\
\hline \multirow[t]{2}{*}{ Prescribing frequency } & $\begin{array}{l}\text { A full one-month course of antiretroviral drugs should be provided for HIV PEP at initial } \\
\text { assessment }\end{array}$ \\
\hline & Starter packs should not be used \\
\hline Frequency of follow-up & Exposed individual should be seen at 2 weeks, 6 weeks and 3 months after exposure occurred \\
\hline Adherence support & Enhanced adherence counselling is recommended for all individuals initiating PEP \\
\hline
\end{tabular}

$\dagger$ See dosing tables in Appendix 1 for dosages.

\footnotetext{
${ }^{11}$ BARC, Johannesburg, South Africa

${ }^{12}$ Lancet Laboratories, Johannesburg, South Africa

Correspondence to: Michelle Moorhouse

Email: mmoorhouse@wrhi.ac.za

Postal address: 22 Esselen Street, Hillbrow, Johannesburg 2001, South Africa

Dates: Published: 15 Dec. 2015

How to cite this article: Moorhouse M, Bekker LG, Black V, et al. Corrigendum: Guideline on the management of occupational and non-occupational exposure to the human immunodeficiency virus and recommendations for post-exposure prophylaxis: 2015 Update. S Afr J HIV Med. 2015;16(1), Art. \#399, 3 pages. http://dx.doi.org/10.4102/sajhivmed.v16i1.399-1

Note: Doi of original article: http://dx.doi.org/10.4102/sajhivmed.v16i1.399

Copyright: @ 2015. The Authors. Licensee: AOSIS OpenJournals. This work is licensed under the Creative Commons Attribution License.
} 


\section{Appendix 1 Dosing tables}

FIGURE 1-A1: Stavudine (d4T); Lopinavir/Ritonavir (LPV/r); Zidovudine (AZT). ${ }^{1}$

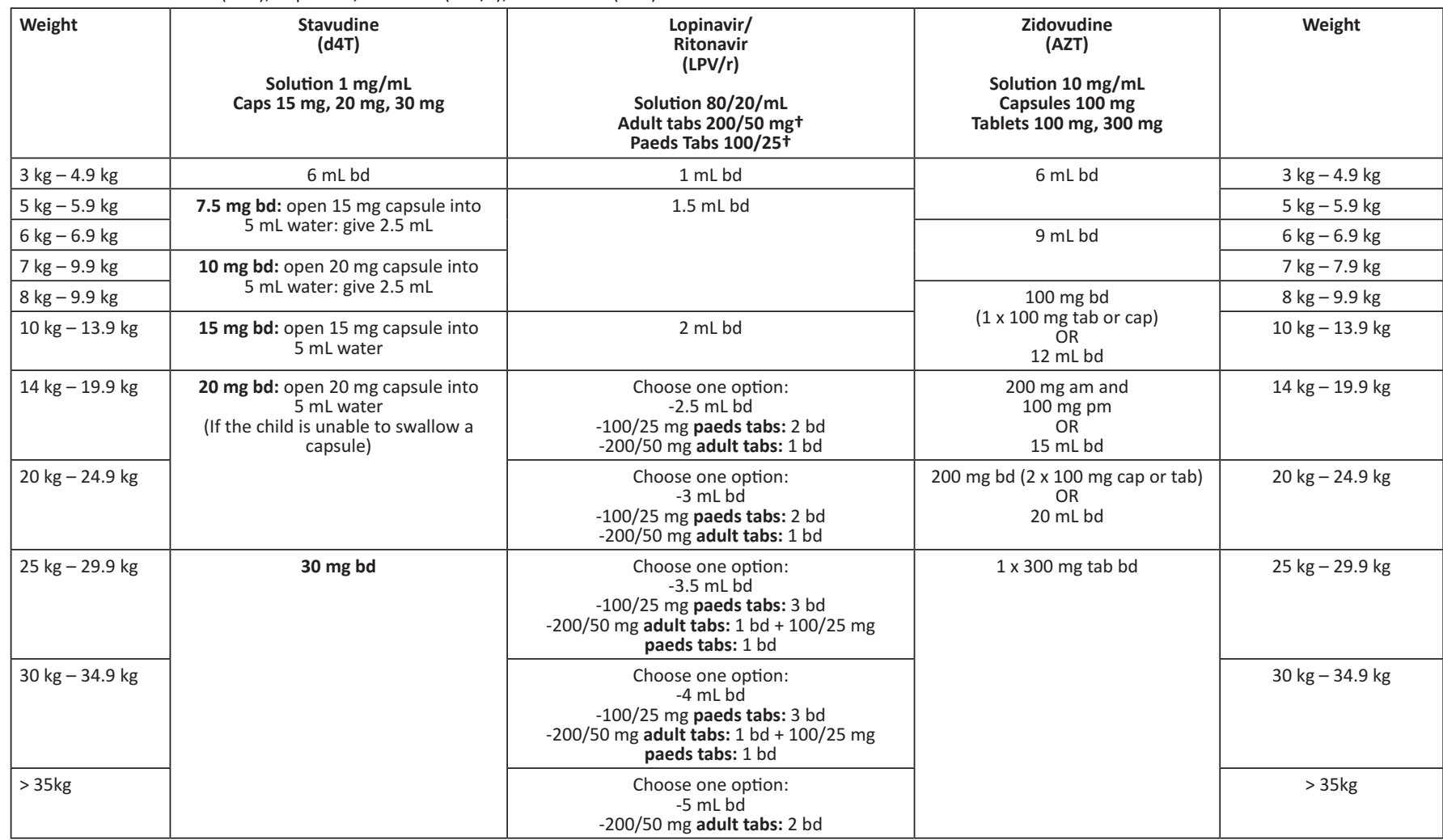

†, Do not crush or break lopinavir/ritonavir tablets.

\section{Raltegravir ${ }^{2}$}

- Chewable tablets and film-coated tablets are not equivalent.

Children aged 2 to $<12$ years:

- $\quad 25 \mathrm{~kg}$ : Chewable tablet twice daily (see dosing chart below)

- $\geq 25 \mathrm{~kg}$ and can swallow tablets: one $400 \mathrm{mg}$ film-coated tablet twice a day

- $\quad 25 \mathrm{~kg}$ and can't swallow tablets: chewable tablets twice daily (see dosing chart below - maximum of $300 \mathrm{mg}$ twice daily).

TABLE 1-A1: Raltegravir chewable tablets.

\begin{tabular}{ll}
\hline Weight (kg) & Number of chewable tablets (100 mg scored or 25 mg) \\
\hline $11 \mathrm{~kg}$ to $<14 \mathrm{~kg}$ & $75 \mathrm{mg}(3 \times 25 \mathrm{mg})$ twice daily \\
$14 \mathrm{~kg}$ to $<20 \mathrm{~kg}$ & $1 \times 100 \mathrm{mg}$ twice daily \\
$20 \mathrm{~kg}$ to $<28 \mathrm{~kg}$ & $150 \mathrm{mg}$ twice daily $(1.5 \times 100 \mathrm{mg})$ \\
$28 \mathrm{~kg}$ to $<40 \mathrm{~kg}$ & $200 \mathrm{mg}(2 \times 100 \mathrm{mg})$ twice daily \\
$\geq 40 \mathrm{~kg}$ & $300 \mathrm{mg}(3 \times 100 \mathrm{mg})$ twice daily \\
\hline
\end{tabular}

\section{Atazanavir ${ }^{2}$}

- Children $\geq 6$ years and $\geq 15 \mathrm{~kg}$. 
TABLE 2-A1: Atazanavir capsules.

Weight (kg) Once daily dose

$<15 \mathrm{~kg} \quad$ Capsules not recommended

$15 \mathrm{~kg}$ to $<20 \mathrm{~kg} \quad$ Atazanavir $150 \mathrm{mg}$ plus ritonavir $+100 \mathrm{mg}$, both once daily with food

$20 \mathrm{~kg}$ to $<40 \mathrm{~kg} \ddagger \quad$ Atazanavir $200 \mathrm{mg}$ plus ritonavir $+100 \mathrm{mg}$ both once daily

with food

$\geq 40 \mathrm{~kg} \quad$ Atazanavir $300 \mathrm{mg}$ plus ritonavir $100 \mathrm{mg}^{\dagger}$ both once daily with food

$\dagger$, Either ritonavir capsules or ritonavir oral solution can be used

$\$$, Some experts would increase atazanavir to $300 \mathrm{mg}$ at $\geq 35 \mathrm{~kg}$ especially when administered

with tenofovi

\section{References}

1. Practice Guidelines SA-HIV Clinicians Society: 2013 ARV Dosing Chart for Children and Adolescents. [cited 2013 Aug 19] Available from: http://www.sahivsoc.org/upload/ documents/ARV\%20dosing\%20chart\%20for\%20children\%202013.pdf

2. Guidelines for the Use of Antiretroviral Agents in HIV-1-Infected Adults and Adolescents. [cited 2015 Nov 25] Available from: http://aidsinfo.nih.gov/guidelines 